\title{
A new broad-spectrum protease inhibitor from the entomopathogenic bacterium Photorhabdus luminescens
}

\author{
Kevin E. Wee, Christopher R. Yonan and F. N. Chang \\ Author for correspondence: F. N. Chang. Tel: +1 215204 8843. Fax: +1 2152046646. \\ e-mail: fchang@nimbus.temple.edu
}

Department of Biology, Temple University, Philadelphia, PA 19122, USA

\begin{abstract}
A new protease inhibitor was purified to apparent homogeneity from a culture medium of Photorhabdus luminescens by ammonium sulfate precipitation and preparative isoelectric focusing followed by affinity chromatography. Ph. luminescens, a bacterium symbiotically associated with the insect-parasitic nematode Heterorhabditis bacteriophora, exists in two morphologically distinguishable phases (primary and secondary). It appears that only the secondary-phase bacterium produces this protease inhibitor. The protease inhibitor has an $M_{\mathrm{r}}$ of approximately 12000 as determined by SDS-PAGE. Its activity is stable over a pH range of 3.5-11 and at temperatures below $50^{\circ} \mathrm{C}$. The $\mathbf{N}$-terminal 16 amino acids of the protease inhibitor were determined as STGIVTFKND(X)GEDIV and have a very high sequence homology with the $\mathrm{N}$-terminal region of an endogenous inhibitor (IA-1) from the fruiting bodies of an edible mushroom, Pleurotus ostreatus. The purified protease inhibitor inactivated the homologous protease with an almost $1: 1$ stoichiometry. It also inhibited proteases from a related insect-nematode-symbiotic bacterium, Xenorhabdus nematophila. Interestingly, when present at a molar ratio of 5 to 1 , this new protease inhibitor completely inactivated the activity of both trypsin and elastase. The activity of proteinase $A$ and cathepsin $G$ was partially inhibited by this bacterial protease inhibitor, but it had no effect on chymotrypsin, subtilisin, thermolysin and cathepsins B and D. The newly isolated protease inhibitor from the secondary-phase bacteria and its specific inhibition of its own protease provides an explanation as to why previous investigators failed to detect the presence of protease activity in the secondary-phase bacteria. The functional implications of the protease inhibitor are also discussed in relation to the physiology of nematode-symbiotic bacteria.
\end{abstract}

Keywords: protease, protease inhibitor, insect nematode, inhibitor-protease interaction

\section{INTRODUCTION}

Photorhabdus luminescens is an entomopathogenic bacterium symbiotically associated with insect-parasitic nematodes of the family Heterorhabditidae, which are used for biological control of many unwanted insects (Poinar et al., 1977; Gaugler \& Kaya, 1990). The bacteria are carried inside the gut of the non-feeding third-instar infective stage nematode (Poinar et al., 1977; Poinar, 1990). Infection occurs when the insectparasitic nematode invades the host insect through

Abbreviation: CBZ-Lys-pNP, N $\alpha$-CBZ-L-lysine $p$-nitrophenyl ester. natural openings such as the mouth, anus or cuticle followed by penetration into the haemocoel of the host. Once inside the haemocoel, the nematode secretes its bacterial symbiont. The bacteria then proliferate within the haemocoel, killing the host insect via septicaemia (Akhurst, 1980; Poinar, 1990). The bacteria also release secondary metabolites and hydrolytic enzymes such as protease, lipase and lecithinase which are essential for the development of progeny nematodes (Schmidt et al., 1988; Boemare \& Akhurst, 1988; Wang \& Dowds, 1993).

$P h$. luminescens bacteria occur in two phases, primary and secondary, which can be distinguished by bio- 
chemical tests, bioluminescence and colony morphology (Akhurst, 1980; Boemare \& Akhurst, 1988). Previous investigators have shown that the primary-phase bacteria are present predominantly in the gut of third-instar infective juvenile nematodes (Akhurst, 1980). It was also reported that only the primary-phase and not the secondary-phase bacteria possess the protease and this characteristic may be used to differentiate these two phases (Schmidt et al., 1988; Nealson et al., 1990; Forst \& Nealson, 1996). Little is known about the regulation of protease activity in these bacteria. In this paper, we show that, contrary to previous reports, both primaryand secondary-phase bacteria synthesize protease. However, in the secondary-phase bacteria the protease activity is suppressed by this newly discovered protease inhibitor. We have purified and partially characterized this protease inhibitor with the aim of providing an explanation of its possible functions.

\section{METHODS}

Materials. Photorhabdus luminescens was obtained from surface-sterilized, infective stage Heterorhabditis bacteriophora HP88 nematodes. Xenorhabdus nematophila was kindly provided by Dr Thomas Schmidt (Indiana University, IN, USA). MacConkey agar was purchased from Sigma. Yeast extract and tryptone were obtained from Difco Laboratories. The Mini-Prep cell, Preparative IEF (Rotofor) unit and Electro-eluter were products of Bio-Rad Laboratories. Azocoll (50 mesh) was obtained from Calbiochem. Trypsin, elastase, proteinase $A$, cathepsin $B$, cathepsin $D$, cathepsin $G$, chymotrypsin, thermolysin, subtilisin, trypsin-acrylic beads as well as the substrates casein-FITC and $N \alpha$-CBZ-L-lysine $p$-nitrophenyl ester (CBZ-Lys-pNP) were products of Sigma. Microcon 3 was purchased from Amicon. All other chemicals were of reagent grade and were obtained from local sources.

Purification of protease from primary-phase $\mathbf{P h}$. luminescens. The primary-phase bacteria were distinguished from the secondary-phase bacteria by colony morphology, presence of luminescence and the ability of the primary form to absorb neutral red from MacConkey agar (Boemare \& Akhurst, 1988). Secondary-phase bacteria were isolated from in vitro cultures initiated from the primary-phase bacteria.

A single Ph. luminescens primary-phase colony was selected from a MacConkey agar plate and grown overnight in $5 \mathrm{ml}$ Luria-Bertani (LB) medium (Sambrook et al., 1989). One millilitre of the inoculum was transferred into $11 \mathrm{LB}$ medium and incubated for $7 \mathrm{~d}$ at $25^{\circ} \mathrm{C}$ in a shaker at 150 r.p.m. Unless otherwise stated, all subsequent operations were carried out in the cold $\left(4^{\circ} \mathrm{C}\right)$. Cells were removed by centrifugation at $7500 \mathrm{~g}$ for $60 \mathrm{~min}$ and the supernatant fraction was carefully collected into a large beaker. Ammonium sulfate was gradually added with stirring to the culture supernatant to $90 \%$ saturation. The precipitate was collected by centrifugation at $7000 \mathrm{~g}$ and then dissolved in $50 \mathrm{mM}$ sodium phosphate buffer, $\mathrm{pH} 7 \cdot 0$. The ammonium sulfate precipitate was dialysed against distilled water overnight. The dialysate was then applied to a Bio-Rad Mini-Prep cell under native conditions and run at $100 \mathrm{~V}$ overnight with a flow rate of $0.75 \mathrm{ml} \mathrm{min}^{-1}$. The fractions containing protease activity (as assayed in the next section) were collected and analysed for purity by PAGE in the presence of SDS. Protease from the X. nematophila primaryphase bacteria was also prepared according to the same procedure.
Assay of protease activity. Protease activity was determined initially using Azocoll as the substrate as described by Schmidt et al. (1988). Eppendorf tubes containing a reaction mixture (total volume $1.2 \mathrm{ml}$ ) consisting of $2 \mathrm{mg}$ Azocoll ml $\mathrm{m}^{-1}$ in $50 \mathrm{mM}$ sodium phosphate buffer $(\mathrm{pH} 7 \cdot 0)$ were prepared. Enzyme solutions $(10-200 \mu \mathrm{l})$ were added to initiate the reaction and the mixture was then incubated at $37^{\circ} \mathrm{C}$. To terminate the reaction, the contents of each tube were centrifuged in an Eppendorf microcentrifuge for $2 \mathrm{~min}$ to remove any undigested Azocoll. The $A_{520}$ of the liberated azo dye from the reaction supernatant was read using a Beckman DU-20 spectrophotometer. One unit of activity was defined as the amount of enzyme that caused an increase in the $A_{520}$ of $0.01 \mathrm{~min}^{-1}$ (Schmidt et al., 1988).

Purification of protease inhibitor from secondary-phase $\mathbf{P h}$. luminescens. A tube containing $5 \mathrm{ml} \mathrm{LB}$ medium was inoculated with a single colony of secondary-phase $\mathrm{Ph}$. luminescens isolated from a MacConkey agar plate and grown for $8 \mathrm{~h}$ at $28{ }^{\circ} \mathrm{C}$ with shaking at 150 r.p.m. One millilitre of this inoculum was transferred to a flask containing $500 \mathrm{ml} \mathrm{LB}$ medium and the culture was grown for $14 \mathrm{~d}$ at $28^{\circ} \mathrm{C}$ with shaking at 150 r.p.m. The cells were removed from the culture medium by centrifugation at $7000 \mathrm{~g}$ for $1 \mathrm{~h}$ at $4{ }^{\circ} \mathrm{C}$. Unless otherwise stated, all subsequent operations were carried out at $4{ }^{\circ} \mathrm{C}$. The supernatant was collected and concentrated by adding ammonium sulfate with stirring to $90 \%$ saturation. The ammonium sulfate precipitate was collected by centrifugation at $9000 \mathrm{~g}$ for $1 \mathrm{~h}$. The pellet was resuspended in $30 \mathrm{ml}$ $50 \mathrm{mM}$ sodium phosphate buffer $(\mathrm{pH} 7 \cdot 0)$ and dialysed against $4 \mathrm{l}$ distilled water overnight with two changes of water. The dialysate was then loaded into a Bio-Rad Rotofor unit, which separates proteins according to their isoelectric points in a liquid medium, using a $\mathrm{pH}$ gradient of $\mathrm{pH} 3-10$. The collected fractions were analysed for inhibitor activity by mixing $50 \mu \mathrm{l}$ of each fraction with $50 \mu \mathrm{l}$ purified protease from the primaryphase $\mathrm{Ph}$. luminescens. The fractions having the highest amount of inhibitor activity were incubated with trypsinacrylic beads. The bound protease inhibitor was then eluted using the Electro-eluter. (In the presence of SDS, the Electroeluter elutes the negatively charged proteins toward the anode, where they are trapped by a $3500 M_{r}$ cut-off dialysis membrane.) SDS was removed from the preparation by exchanging the lower buffer halfway through the run according to the manufacturer's protocol. The purity of the inhibitor was analysed using discontinuous SDS-PAGE. Protein concentration was determined by the Bradford microassay method (Bradford, 1976).

Stoichiometry of protease-protease inhibitor interaction. Ten microlitres of a $100 \mathrm{nM}$ purified protease from primaryphase $\mathrm{Ph}$.luminescens was incubated with various amounts of purified protease inhibitor from secondary-phase $\mathrm{Ph}$. luminescens and allowed to react for $20 \mathrm{~min}$ at room temperature. Since the azocoll method used previously was rather insensitive, a different substrate (CBZ-Lys-pNP) was used for the stoichiometry study. Twenty microlitres of $50 \mu \mathrm{M}$ CBZLys-pNP substrate was then added to the reaction mixture and further incubated for $10 \mathrm{~min}$ at $37^{\circ} \mathrm{C}$. The reaction was terminated by adding $700 \mu \mathrm{l}$ ice-cold $0.2 \mathrm{M}$ sodium acetate buffer ( $\mathrm{pH} 4 \cdot 0$ ) and the $A_{326}$ was read immediately in a Beckman DU-20 spectrophotometer (Twining, 1994). Protease inhibitor activity was determined as the percentage of protease activity remaining when compared to the control tube containing buffer alone.

Activity spectrum of purified protease inhibitor. To study the activity spectrum of the purified protease inhibitor, it was 
necessary to use a general protease substrate, and casein-FITC (Twining, 1994) was found to be an ideal substrate for this purpose. The following proteases were used: primary-phase proteases purified from both $\mathrm{Ph}$. luminescens and $X$. nematophila, proteinase A, cathepsin B, cathepsin D, cathepsin G, chymotrypsin, elastase, thermolysin, subtilisin and trypsin. Each protease was diluted in $50 \mathrm{mM}$ sodium phosphate buffer $(\mathrm{pH} 6.5)$ and adjusted to its $\mathrm{pH}$ optimum according to the protocol suggested by Sigma Chemicals, except for cathepsin $\mathrm{D}$, which was diluted in $50 \mathrm{mM}$ sodium acetate buffer at $\mathrm{pH}$ $3 \cdot 5$. The assay mixture contained $5 \mu \mathrm{l} 20 \mathrm{nM}$ protease and $5 \mu \mathrm{l}$ $100 \mathrm{nM}$ protease inhibitor. After incubating at room temperature for $20 \mathrm{~min}, 20 \mu \mathrm{l}$ casein-FITC $\left(1 \mathrm{mg} \mathrm{ml}^{-1}\right)$ and $100 \mu \mathrm{l}$ $50 \mathrm{mM}$ buffer at the appropriate $\mathrm{pH}$ were added. The mixture was then incubated at $37^{\circ} \mathrm{C}$ for $30 \mathrm{~min}$ and the reaction was stopped by adding $100 \mu \mathrm{l} 5 \%$ TCA. The undigested casein-FITC was removed by centrifugation at 14000 r.p.m. in an Eppendorf microfuge for $3 \mathrm{~min}$. Two hundred microlitres of supernatant was transferred to a tube containing $500 \mu \mathrm{l} 0 \cdot 2 \mathrm{M}$ sodium phosphate buffer $(\mathrm{pH} \mathrm{7 \cdot 8)}$ to neutralize the TCA. Inhibitor activity was determined as percentage of activity remaining when compared to a control tube containing only buffer, using an Amicon fluorimeter (excitation at $492 \mathrm{~nm}$ and emission at $515 \mathrm{~nm}$ ).

pH stability of the protease inhibitor. Five microlitres of protease inhibitor was diluted in $50 \mu \mathrm{l}$ of buffers of overlapping $\mathrm{pH}$ ranges from $\mathrm{pH} 3.5$ to 11.0 and incubated at room temperature for $1 \mathrm{~h}$. Microcon 3 was then used to exchange buffers to $50 \mathrm{mM}$ sodium phosphate buffer, $\mathrm{pH} 6 \cdot 8$. Residual inhibitor activity was assayed against purified protease from primary-phase $\mathrm{Ph}$. luminescens. The assay contained $10 \mu \mathrm{l}$ $10 \mathrm{nM}$ enzyme and $50 \mu \mathrm{l} 10 \mathrm{nM} \mathrm{pH}$-adjusted protease inhibitor and the reaction mixture was incubated at room temperature for $20 \mathrm{~min}$. Casein-FITC $(20 \mu \mathrm{l})\left(1 \mathrm{mg} \mathrm{ml}^{-1}\right)$ and $40 \mu \mathrm{l} 50 \mathrm{mM}$ sodium phosphate buffer ( $\mathrm{pH} 6 \cdot 8$ ) were then added and the reaction mixture was further incubated at $37^{\circ} \mathrm{C}$ for $30 \mathrm{~min}$. The reaction was then stopped with $100 \mu \mathrm{l} 5 \%$ TCA and the undigested casein-FITC was removed by centrifugation at 14000 r.p.m. in an Eppendorf microfuge for $3 \mathrm{~min}$. Two hundred microlitres of supernatant was transferred to a tube containing $500 \mu \mathrm{l} 0 \cdot 2 \mathrm{M}$ sodium phosphate buffer $(\mathrm{pH} 7 \cdot 8)$ to neutralize the TCA. Protease inhibitor activity was determined fluorimetrically relative to the control as described previously.

Thermal stability of protease inhibitor. Eppendorf tubes containing $5 \mu \mathrm{l}$ protease inhibitor were incubated over a range of temperatures between 25 and $100{ }^{\circ} \mathrm{C}$ for $1 \mathrm{~h}$ and subsequently adjusted to $37^{\circ} \mathrm{C}$. The adjusted protease inhibitor was mixed with $10 \mu \mathrm{l}$ primary-phase protease and the activity was assayed as described previously.

$\mathbf{N}$-terminal peptide sequencing of purified inhibitor from $\mathbf{P h}$. luminescens. Protein sequence determination was performed by Dr Joe Lykam of Michigan State University Department of Macromolecular Biochemistry (East Lansing, MI, USA).

\section{RESULTS}

As indicated earlier, bacteria symbiotically associated with insect-parasitic nematodes exist in two morphologically distinguishable phases - primary and secondary (Boemare \& Akhurst, 1988). Previous investigators have reported that only the primary-phase bacteria contained the protease activity (e.g. Schmidt et al., 1988). While studying proteases from various nematodesymbiotic bacteria, we have confirmed that a number of
Table 1. Protease activity of nematode-symbiotic bacteria

One activity unit was defined as a change in $A_{520}$ of $0 \cdot 01 \mathrm{~min}^{-1}$ $(\mathrm{mg} \text { protein })^{-1}$ using the azocoll assay as described in Methods. Each sample contained $33.3 \mu \mathrm{g}$ total protein from cell-free culture supernatant. The experiment was performed in triplicate.

\begin{tabular}{|lll|}
\hline Bacterium & Phase & $\begin{array}{c}\text { Protease } \\
\text { activity (unit) }\end{array}$ \\
\hline X. nematophila & Primary & $0 \cdot 959 \pm 0 \cdot 031$ \\
X. nematophila & Secondary & $0 \cdot 651 \pm 0 \cdot 005$ \\
Ph. luminescens & Primary & $0 \cdot 360 \pm 0 \cdot 013$ \\
Ph. luminescens & Secondary & $0 \cdot 017 \pm 0 \cdot 016$ \\
\hline
\end{tabular}

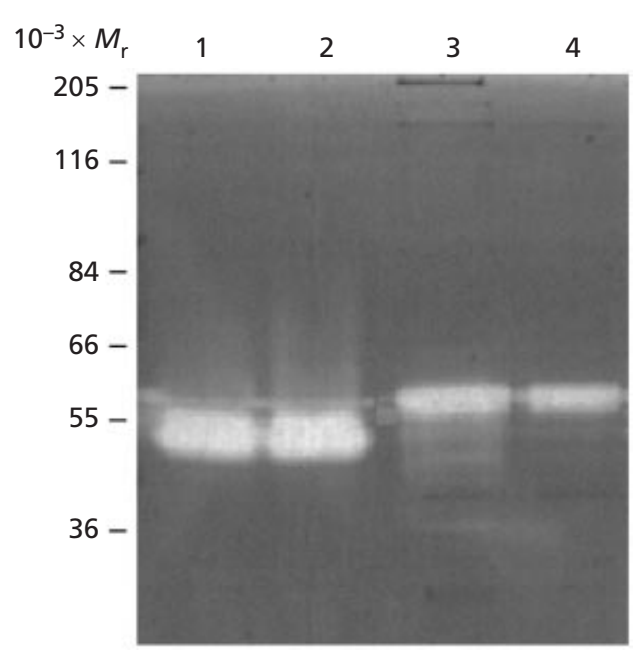

Fig. 1. SDS-PAGE zymogram of protease activity from both primary and secondary cultures of $X$. nematophila and $P h$. luminescens. Ten microlitres of supernatant from 7-d-old cultures was used and loaded onto a $12 \%$ polyacrylamide gel in the presence of $0.05 \%$ gelatin and stained with Coomassie blue (Ong \& Chang, 1997). Lanes: 1, protease from primary-phase $X$. nematophila; 2, protease from secondary-phase $X$. nematophila; 3, protease from primary-phase Ph. luminescens; 4 , protease from secondary-phase Ph. luminescens.

secondary-phase bacteria had extremely low protease activity but were puzzled by high protease activity exhibited by other secondary-phase bacteria. For example, Table 1 shows that unlike $P h$. luminescens, both primary and secondary phases of X. nematophila produced high protease activity. Analysis of both primary and secondary phases of X. nematophila and $P h$. luminescens by zymography confirmed the presence of high protease activity in X. nematophila (Fig. 1). Unexpectedly, it also showed that the secondary phase of $\mathrm{Ph}$. luminescens also contained very high protease activity (Fig. 1, lane 4). A possible explanation for this apparent contradiction is the presence of an inhibitor(s) in the secondary phase of $\mathrm{Ph}$. luminescens. An attempt was therefore made to isolate such a protease inhibitor. 
Table 2. Purification of protease inhibitor from secondary-phase Ph. luminescens

One unit of inhibitor activity was defined as the amount of protease inhibitor that caused a $50 \%$ reduction in protease activity when compared to a control at $520 \mathrm{~nm}$ using the azocoll assay as described in Methods. Specific activity was defined as units $\mathrm{mg}^{-1}$.

\begin{tabular}{|c|c|c|c|c|c|c|c|}
\hline Step & Fraction & $\begin{array}{l}\text { Total volume } \\
(\mathrm{ml})\end{array}$ & $\begin{array}{c}\text { Total protein } \\
(\mathbf{m g})\end{array}$ & Total units & $\begin{array}{l}\text { Specific activity } \\
\text { (units } \mathrm{mg}^{-1} \text { ) }\end{array}$ & $\begin{array}{c}\text { Purification } \\
\text { (-fold) }\end{array}$ & Yield $(\%)$ \\
\hline I & Crude extract & $500 \cdot 0$ & $415 \cdot 00$ & 51875 & 125 & 1 & 100 \\
\hline II & $\left(\mathrm{NH}_{4}\right)_{2} \mathrm{SO}_{4}$ precipitation & $48 \cdot 0$ & $144 \cdot 00$ & 37440 & 260 & 2 & 72 \\
\hline III & IEF & $6 \cdot 0$ & $3 \cdot 20$ & 12308 & 3846 & 31 & 24 \\
\hline IV & Affinity chromatography & $3 \cdot 6$ & $0 \cdot 18$ & 8280 & 46000 & 368 & 16 \\
\hline
\end{tabular}

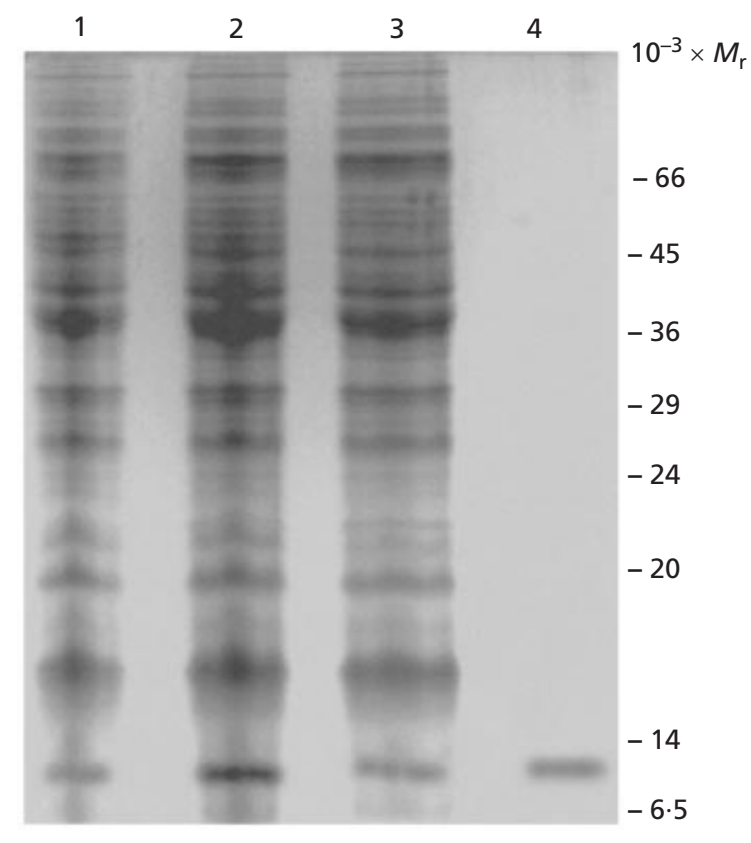

Fig. 2. SDS-PAGE analysis of protein composition at various stages of purification of the protease inhibitor. Lanes: 1 , crude cell-free culture; 2, ammonium sulfate precipitate; 3, trypsin bead unbound fraction; 4, elution of bound proteins from trypsin beads. Visualization of proteins was carried out by silver staining.

\section{Purification of the protease inhibitor from secondary- phase Ph. luminescens}

Since protease inhibitor has not been reported in bacteria symbiotically associated with insect-parasitic nematodes, a purification scheme was developed using preparative isoelectric focusing and affinity chromatography. Both primary- and secondary-phase $\mathrm{Ph}$. luminescens were examined for the presence of protease inhibitor activity. Protease inhibitor was only found in the secondary-phase bacteria. Table 2 shows that the protease inhibitor from the secondary-phase $\mathrm{Ph}$. luminescens was purified 368 -fold with a $16 \%$ yield. The purity of the protease inhibitor together with the protein composition at various steps of the purification process are shown in Fig. 2. The SDS-PAGE reveals that the purified inhibitor has an apparent $M_{\mathrm{r}}$ of approxi- mately 12000 . We have also confirmed that this protein band contained protease inhibitor activity by transferring it to nitrocellulose paper using capillary blotting followed by assaying for inhibitory activity using the procedure of Ohlsson et al. (1986) (results not shown).

\section{$\mathrm{pH}$ and heat stability of the protease inhibitor}

To test the $\mathrm{pH}$ stability of the protease inhibitor, it was incubated at room temperature for $1 \mathrm{~h}$ in the $\mathrm{pH}$ range 3.5-11.0. Residual inhibitor activity was measured as described in Methods. Interestingly, the protease inhibitor retained its full activity when it was exposed to the $\mathrm{pH}$ range tested. The thermal stability of the inhibitor was assayed within the range of $25-100^{\circ} \mathrm{C}$; it was inactivated when the temperature was above $50{ }^{\circ} \mathrm{C}$ (results not shown).

\section{Determination of the $\mathrm{N}$-terminal amino acid sequence of the protease inhibitor}

After localization of inhibitory activity, the protease inhibitor band was excised from the polyacrylamide gel and subjected to amino acid sequence determination. The N-terminal 16 amino acids of the purified protease inhibitor were determined as STGIVTFKND(X)GEDIV (residue 11 appears to be modified). A sequence search was performed and it was found that it bears high sequence homology to the N-terminal region of an endogenous inhibitor (IA-1) from the fruiting bodies of an edible mushroom, Pleurotus ostreatus (Dohmae et al., 1995). As shown below, 11 of the first 15 amino acids $(73 \%)$ were identical between these two protease inhibitors.

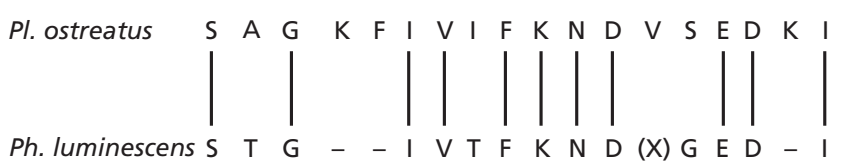

Interestingly, both protease inhibitors start with the serine residue, although in the mushroom it is acetylated, suggesting its cytosolic location (Odani et al., 1999). The 


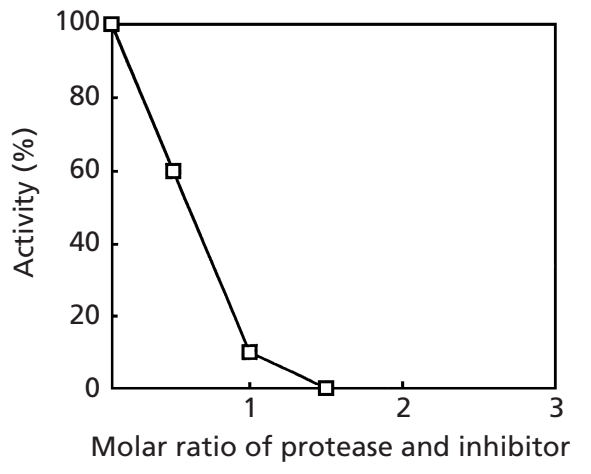

Fig. 3. Inhibition of protease activity from Ph. luminescens by its homologous protease inhibitor. Primary-phase protease was incubated with various amounts of secondary-phase protease inhibitor and the remaining protease activity was assayed as described in Methods.

Table 3. Activity of protease inhibitor against various proteases

Various protease enzymes (homologous and heterologous) at a concentration of $20 \mathrm{nM}$ were assayed against protease inhibitor from the secondary phase of $\mathrm{Ph}$. luminescens $(100 \mathrm{nM})$. Casein-FITC $\left(1 \mathrm{mg} \mathrm{ml}^{-1}\right)$ was used as the substrate. The assay was read in an Amicon fluorimeter (excitation at $492 \mathrm{~nm}$, emission at $515 \mathrm{~nm}$ ) as described in Methods.

\begin{tabular}{|lc|}
\hline Protease & Inhibition $(\%)$ \\
\hline Ph. luminescens (primary) & $100 \pm 3$ \\
X. nematophila (primary) & $87 \pm 5$ \\
Trypsin & $100 \pm 3$ \\
Elastase & $100 \pm 5$ \\
Proteinase A & $68 \pm 2$ \\
Cathepsin G & $41 \pm 5$ \\
Cathepsin B & $0 \pm 5$ \\
Cathepsin D & $0 \pm 3$ \\
Chymotrypsin & $0 \pm 3$ \\
Thermolysin & $0 \pm 3$ \\
Subtilisin & $0 \pm 3$ \\
\hline
\end{tabular}

$\mathrm{Ph}$. luminescens protease inhibitor, on the other hand, is a secretory protein.

\section{Protease-protease inhibitor interaction}

In order to study the nature of the interaction between the newly isolated protease inhibitor and its substrates, it was necessary to purify proteases from different nematode-symbiotic bacteria. The culture medium from the primary-phase $\mathrm{Ph}$. luminescens was subjected to ammonium sulfate precipitation, dialysis and preparative PAGE under native conditions as described in Methods. A single band containing protease activity was observed with an apparent $M_{r}$ of 56000 (figure not shown). The ability of protease inhibitor from $\mathrm{Ph}$. luminescens to inhibit its homologous protease was then examined. Fig. 3 shows that at a molar ratio of one to one, $90 \%$ of the protease activity was inhibited, indicating an almost stoichiometric interaction between the protease and its inhibitor.

Protease from $X$. nematophila was similarly purified with an apparent $M_{\mathrm{r}}$ of 53000 (figure not shown). The effect of Ph. luminescens protease inhibitor on protease activity from $X$. nematophila and several other proteases was also carried out using a molar ratio of 5 to 1 in favour of protease inhibitor. Table 3 shows that the $X$. nematophila protease was $87 \%$ inhibited by the heterologous protease inhibitor from $\mathrm{Ph}$. luminescens. Interestingly, the purified protease inhibitor was able to completely inhibit the activity of both trypsin and elastase. The activity of proteinase $\mathrm{A}$ and cathepsin G was partially inhibited. However, chymotrypsin, cathepsin B, cathepsin D, thermolysin and subtilisin were not affected by the protease inhibitor.

\section{DISCUSSION}

The demonstration that both primary- and secondaryphase bacteria produced the protease (Fig. 1) called into question the commonly held notion that only the primary-phase bacteria contain the protease activity (e.g. Schmidt et al., 1988). The failure to detect protease activity in the secondary-phase bacteria by other investigators can now be traced to the presence of the newly discovered protease inhibitor that suppressed the protease activity. The function of proteases in mammalian systems has been well studied and they are reported to be involved in processes such as the blood clotting cascade, cell cycle, activation of precursor proteins, processing and degradation of proteins and cellular development (for a review, see Travis \& Potempa, 2000). Proteases have also been implicated in morphological differentiation and mycelium growth of Streptomyces albidoflavus, a Gram-positive soil bacterium widely known for possessing a variety of hydrolytic enzymes (Kang \& Lee, 1997). The expression of the protease gene in this bacterium is found to be dependent upon the proteinaceous nutrients in the environment (Taguchi et al., 1998). Protease inhibitors have been suggested to modulate these proteasemediated reactions (Travis \& Potempa, 2000).

Since $P h$. luminescens is a symbiont of insect-parasitic nematodes, several properties of the protease inhibitor suggest that it may participate in the parasitization process. First, the protease inhibitor is rather unusual in that it retains full activity in the $\mathrm{pH}$ range tested $(3 \cdot 5-11 \cdot 0)$. This broad $\mathrm{pH}$ range not only covers the $\mathrm{pH}$ of insect haemolymph, where the bacteria are initially released by insect nematodes, but also the gut $\mathrm{pHs}$ of various insects. It is known that both the lepidopteran and dipteran insects have rather alkaline guts whereas the coleopteran insects have acidic guts (McFarlane, 
1985). The fact that $\mathrm{Ph}$. luminescens protease inhibitor is active at these gut $\mathrm{pHs}$ indicates that it may interfere with the insect's digestive system and speed up the parasitization process. The exceedingly high homology between $\mathrm{Ph}$. luminescens protease inhibitor and that produced by the fruiting bodies of an edible mushroom, $\mathrm{Pl}$. ostreatus, used to defend against ingestion by insects, lends further support to the role of protease inhibitor in controlling the digestive processes of the insect host. Second, the protease inhibitor was found to suppress insect proteases that are required to activate the prophenoloxidase cascade essential for the insect defensive system (Kanost, 1999; Park et al., 2000). Although we have not tested the activity of $\mathrm{Ph}$. luminescens protease inhibitor against various insect proteases, the broad spectrum of the protease inhibitor (Table 3) suggests that it will inactivate the insect proteases.

The protease inhibitor may also be involved in regulating the bacterial phase shift during the development of insect nematodes. It is known that the primary-phase bacteria are present predominantly in the gut of insect-parasitic nematodes (Akhurst, 1980) and it is clearly advantageous to have high protease activity during the initial stage of the infection process inside a target insect host rich in proteinaceous nutrients. At later stages of infection when the nutrients are depleted, it will be necessary to control or curtail this protease activity. One way to regulate the protease activity is to convert some primary-phase bacteria, which apparently do not produce protease inhibitor or may have produced so small an amount that it escaped detection, into the secondary phase. It has been documented that when cultured in vitro, primary-phase $\mathrm{Ph}$. luminescens can easily be converted to the secondary phase and this process appears to be irreversible (Bleakley \& Nealson, 1988; Forst \& Nealson, 1996). An alternative method for controlling the protease activity is to suppress the growth of the primary-phase bacteria at later stages of parasitization, thereby allowing the secondary-phase bacteria to populate. In this regard, Smigielski et al. (1994) showed that the secondary-phase bacteria can grow twice as fast in vitro when compared to the primary-phase bacteria. It has also been reported that in Streptomyces albogriseolus, overproduction of protease (due to a deletion mutation in the protease inhibitor gene) leads to a marked decrease in growth rate (Taguchi et al., 1998). It is likely that the secondary-phase $P h$. luminescens bacteria without the burden of high protease activity can outgrow the primary phase and be dominant in a mixed culture when nutrients become limiting. Our results indicate that rather than being perceived primarily as an in vitro artefact, secondaryphase $P h$. luminescens may actually be quite critical to the development of insect nematodes.

\section{ACKNOWLEDGEMENTS}

We would like to thank Dr Sally Twining, Department of Biochemistry, Medical College of Wisconsin, for suggesting the use of casein-FITC as a general substrate and her advice on this project.

\section{REFERENCES}

Akhurst, R. J. (1980). Morphological and functional dimorphism in Xenorhabdus spp., bacteria symbiotically associated with the insect pathogenic nematodes Neoplanta and Heterorhabditis. J Gen Microbiol 121, 303-309.

Bleakley, B. \& Nealson, K. H. (1988). Characterization of primary and secondary form of Xenorhabdus luminescens strain $\mathrm{Hm}$. FEMS Microbiol Ecol 53, 241-250.

Boemare, N. \& Akhurst, R. J. (1988). Biochemical and physiological characterization of colony form variants in Xenorhabdus spp. (Enterobacteriaceae). J Gen Microbiol 134, 751-761.

Bradford, M. (1976). A rapid and sensitive method for the quantitation of microgram quantities of protein utilizing the principle of protein-dye binding. Anal Biochem 72, 248-254.

Dohmae, N., Takio, K., Tsumuraya, Y. \& Hashimoto, Y. (1995). The complete amino acid sequence of two serine proteinase inhibitors from the fruiting bodies of a Basidiomycete, Pleurotus ostreatus. Arch Biochem Biophys 316, 498-506.

Forst, S. \& Nealson, K. (1996). Molecular biology of the symbioticpathogenic bacteria Xenorhabdus spp. and Photorhabdus spp. Microbiol Rev 60, 21-43.

Gaugler, R. \& Kaya, H. K. (1990). Entomopathogenic Nematodes in Biological Control. Boca Raton, FL: CRC Press.

Kang, S. G. \& Lee, K. J. (1997). Kinetic analysis of morphological differentiation and protease production in Streptomyces albidoflavus SMF301. Microbiology 143, 2709-2714.

Kanost, M. R. (1999). Serine proteinase inhibitors in arthropod immunity. Dev Comp Immunol 23, 291-301.

McFarlane, J. E. (1985). Nutrition and digestive organs. In Fundamentals of Insect Physiology, pp. 59-89. Edited by M. S. Blum. New York: Wiley.

Nealson, K. H., Schmidt, T. M. \& Bleakley, B. (1990). Physiology and biochemistry of Xenorhabdus. In Entomopathogenic Nematodes in Biological Control, pp. 271-284. Edited by R. Gaugler \& H. Kaya. Boca Raton, FL: CRC Press.

Odani, S., Tominaga, K., Kondou, S., Hori, H., Koide, T., Hara, S., Isemura, M. \& Tsunasawa, S. (1999). The inhibitory properties and primary structure of a novel serine proteinase inhibitor from the fruiting body of the basidiomycete, Lentinus edodes. Eur J Biochem 262, 915-923.

Ohlsson, B. G., Westrom, B. R. \& Karlsson, B. W. (1986). Enzymoblotting: a method for localizing proteinases and their zymogens using para-nitroanilide substrates after agarose gel electrophoresis and transfer to nitrocellulose. Anal Biochem 152, 239-244.

Ong, K. L. \& Chang, F. N. (1997). Analysis of proteins from different phase variants of the entomopathogenic bacteria $P$. luminescens by two-dimensional zymography. Electrophoresis 18, 834-839.

Park, D. S., Shin, S. W., Hong, S. D. \& Park, H. Y. (2000). Immunological detection of serpin in the fall webworm, $H y$ phantria cunea and its inhibitory activity on the prophenoloxidase system. Mol Cells 10, 186-192.

Poinar, G. (1990). Biology and taxonomy of Steinermatidae and Heterorhabditidae. In Entomopathogenic Nematodes in Biological Control, pp. 23-62. Edited by R. R. Gaugler \& H. K. Kaya. Boca Raton, FL: CRC Press. 
Poinar, G. O., Jr, Thomas, G. M. \& Hess, R. (1977). Characteristics of the specific bacterium associated with Heterorhabditis bacteriophora (Heterorhabditidae: Rhabditida). Nematologica 23, 97-102.

Sambrook, J., Fritsch, E. F. \& Maniatis, T. (1989). Molecular Cloning: a Laboratory Manual, 2nd edn. Cold Spring Harbor, NY: Cold Spring Harbor Laboratory.

Schmidt, T. M., Bleakley, B. \& Nealson, K. H. (1988). Characterization of an extracellular protease from the insect pathogen Xenorhabdus luminescens. Appl Environ Microbiol 54, 2793-2797.

Smigielski, A., Akhurst, R. J. \& Boemare, N. E. (1994). Phase variation in Xenorhabdus nematophilus and Photorhabdus luminescens: differences in respiratory activity and membrane energization. Appl Environ Microbiol 60, 120-125.

Taguchi, S., Yamada, S. K. \& Momose, H. (1998). An endogenous target protease, SAM-P26, of Streptomyces protease inhibitor (SSI): primary structure, enzymatic characterization and its interaction with SSI. J Biochem 124, 804-810.

Travis, J. \& Potempa, J. (2000). Bacterial proteinases as targets for the development of second-generation antibiotics. Biochim Biophys Acta 1477, 35-50.

Twining, S. S. (1994). Regulation of proteolytic activity in tissues. Crit Rev Biochem Mol Biol 29, 315-383.

Wang, H. \& Dowds, B. C. (1993). Phase variation in Xenorhabdus luminescens: cloning and sequencing of the lipase gene and analysis of its expression in primary and secondary phases of the bacterium. J Bacteriol 175, 1665-1673.

Received 20 April 2000; revised 14 August 2000; accepted 21 August 2000. 